\title{
Pre-Service Beginning Teachers' Beliefs, Expectations and Other Teacher Preparation Issues of the Practicum at the University of Trinidad and Tobago
}

\author{
George Gowrie \& Mala Ramdass \\ University of Trinidad and Tobago \\ E-mail: georgegowrie@hotmail.com \& mala.ramdass@utt.edu.tt
}

Received: July 30, 2012

Accepted: October 10, 2012

Online Published: October 15, 2012

doi:10.5430/ijhe.v1n2p184

URL: http://dx.doi.org/10.5430/ijhe.v1n2p184

\begin{abstract}
The study examined the extent to which there were changes in pre-service teachers' beliefs, expectations and other teacher preparation issues over a four-year period at the University of Trinidad and Tobago. The study was guided by the conceptual framework of Calderhead and Shorrock (1997) - the personal, critical, academic, practical and technical orientation - and compared pre-service teachers' reflections on these five components before and after their exposure to the practicum at the university. The participants in the study were 36 pre-service beginning teachers who were never exposed to any teacher training programme. There were 12 males and 24 females whose average ages were 24 years. Data were collected through in-depth semi-structured interviews at the beginning and the end of the four year period. The interview data were audio-taped and later transcribed in the tradition of grounded theory (Glaser and Strauss, 1967). Systematic coding was used to uncover key features and emerging themes from the first and second phases of the study. Five categories consistent with the conceptual framework of the study were identified: beliefs and expectations, mentorship support, resource adequacy, content and pedagogical knowledge and adequate classroom experiences. The findings suggested there were some changes in pre-service beliefs and expectations and other preparation issues. There were also mixed messages from the beginning teachers with regard to adequate resources, mentorship support and classroom experiences. Recommendations were made for the continuing professional development of these novice teachers.
\end{abstract}

Keywords: Pre-service, Beginning teachers, Practicum, Mentoring, Cooperating teacher

\section{Introduction}

Pre-service beginning teachers have a well- developed set of personal beliefs about learning and teaching prior to entering their teacher preparation programme. These beliefs constitute meaning that these novices have constructed on the basis of their personal experiences and cultural backgrounds (Hollins, 2011). While some research studies on teachers' prior beliefs make the point that these beliefs are resistant to change (Kagan, 1992), others argue that there are changes in beginning teachers beliefs and expectations over time (Feiman-Nemser, 2001). A number of related studies on teacher education have further explored the need to study novice teachers' beliefs, expectations and perceptions so that these beginning teachers may become more reflective in their professional practice (Wilson and I'Anson, 2006).

This research addressed the extent to which pre-service beginning teachers with no prior teaching experience were of the view that there were changes in their beliefs and expectations during the process of learning to teach over a four year period. It also addressed some of the challenges these teachers are faced with such as making closer links between theory and practice and adequacy of mentoring and resources.

\subsection{Background and Context}

Trinidad and Tobago, a twin-island state, is the most southerly of all the Caribbean islands. The island, after five centuries of foreign domination, gained its independence from Britain in 1962. The Trinidad and Tobago possesses a British-oriented model of bureaucracy, which is reflected in the education system. Within Trinidad and Tobago's education system, there are government schools, which are fully owned and operated by the state; government-assisted or denominational schools, which are managed by a private body (usually a religious denomination) but given financial assistance by the state; private schools, which are maintained and operated by 
private bodies without the assistance from the state; and special schools, which are designed for educating children with special needs and which provide education mainly at the primary level. Generally speaking, the government-assisted schools are regarded as the better schools and there is a great demand for placement for children in these schools.

At present there are approximately 454 public primary schools in eight Education Districts in Trinidad and Tobago. Of these, 322 are government-assisted or denominational and 132 are government schools. Primary schooling is compulsory from age six to fourteen, but children may be admitted from age five and may remain enrolled until fifteen unless selected for secondary schooling at 11+. The transition from primary to secondary school is largely determined by performance at the Secondary Entrance Assessment (SEA). Students at 11+ are examined in three subject areas: Mathematics, Language Arts and Creative Writing, the results of which determine whether students are placed in schools of their choice or at the discretion of the Ministry of Education.

\subsection{Teacher Education in Trinidad and Tobago}

From the 1970's up until 2006 teacher education was in-service training resulting in the award of a Teachers' Diploma after two years of teacher training. During this time an untrained teacher entered two Teacher Training Colleges on government scholarships after having served as an Assistant Teacher for two to three years in primary schools. The minimum entry requirement into the Teachers' College Diploma programme was Cambridge or Oxford Universities General Certificate of Education (GCE) passes at Ordinary Level (O'Levels) or five (from 1979) Caribbean Secondary Education Certificate( CSEC) administered by the Caribbean Examinations Council (CXC) of which passes in Mathematics, English and Science were compulsory. At the Teachers' Colleges the prospective teachers were exposed to a wide range of pedagogical content courses and the option to select an elective specialization from among the core disciplines offered for study. The classroom teaching at the Teachers' Colleges was substantiated by twelve weeks of examined practicum over the two year period. Teacher education over the two year period was controlled by the Ministry of Education through a Board of Teacher Training.

In 2006 the model of teacher education described above underwent radical change based on the recommendation of the White Paper (1999-2003) to rationalize teacher education in Trinidad and Tobago. One of the recommendations was the replacement of the in-service two year Teachers' Diploma by a four - year pre-service Bachelor of Education (B.Ed) programme. The minimum requirement for entry into the Bachelor of Education Programme is the same as those required for the previous two-year Teachers' Diploma. The University of Trinidad and Tobago (UTT) established in 2004 replaced the Teachers' Colleges for the provision of teacher training at the primary level.

Indeed, the educational landscape in Trinidad and Tobago has, thus, reflected, to a considerable degree, the broad trends that have marked the processes of educational reform in most countries of the Western world. One such reform initiative, as mentioned above, has been the replacement of the two-year Teacher Diploma with the four-year Bachelor of Education.

\subsection{The Practicum}

The University of Trinidad and Tobago offers a 4-year Bachelor of Education Degree Program for pre-service prospective teachers, consisting of a wide range of content and pedagogical courses and the practicum. The eight-course practicum programme was implemented as part of the B.Ed. from September 2008. It is designed to provide pre-service beginning teachers with practical experience of teaching to help them develop and deepen their practical knowledge and 'wisdom of practice' (Shulman, 1987; Flores and Day, 2006)). Over the four year period the pre-service teachers are exposed to eight practicum courses which are geared to provide them with: 1.) an understanding of the practical circumstances in which teachers work (personal practical knowledge); 2.) an opportunity to develop and deepen their knowledge from classroom situations and the tasks of teaching ( classroom knowledge); 3.) ways to develop their knowledge on how to teach in different class contexts ( pedagogical content knowledge) and 4.) opportunities to link their theoretical understandings of teaching with their practical experiences of teaching and learning in an authentic learning environment.

In the first year students reflect on their reasons for choosing to become teachers as they explore their past experiences of teaching and learning and examine what they imagine to be the various roles and responsibilities as teachers. Also, they engage in interactive discussions on teacher professionalism. In addition to weekly class meetings, there are field observation visits during which the pre-service teachers make sense of the way in which schools are organized and explore the roles of principals, teacher, parents and the wider community in educational settings. 
In the second year the focus is on in-house planning and teaching. Prospective teachers explore ideas about teaching and learning, plan, evaluate lessons for diverse classrooms with peers and supervisors and develop their own communication and inter-personal skills as they engage with relevant educational research. Also, there are field-teaching visits during which the prospective teachers discuss classroom strategies, plan and deliver lessons in real-life classrooms and reflect upon cooperating teachers' behavior and interactions in their respective classes.

During the third year the pre-service teachers deepen their field experience as they explore a range of innovative strategies and make links between their teaching and the understanding of their students. There are also class meetings and discussions to reflect on the changes in the prospective teachers' beliefs and practices about teaching and learning.

The final teaching practice involves individual teaching in actual classrooms over a six week period. Students plan lessons using a variety of instructional strategies, methods and assessment strategies. The student teachers evaluate lessons with their practicum advisors and use a variety of classroom management techniques as they shape their experiences of training to be a teacher.

The practicum builds on two major practices that may help beginning teachers develop an understanding of the importance of working with other teachers. The first is the concept of the community of learners. Such a concept helps to establish a positive classroom environment that enhances the learning experience of students so that their contributions are valued and their learning needs are addressed (Tompkins, 2006). The same groups of students are maintained in a practicum group for the two courses offered in the year. The second is that of co-teaching (Nokes, Boulough, Egan, Birrell, and Hansen, 2008) which is an integral part of the practicum programme. Zwart, Wubbles, and Bergen, Bolhuis (2009) examined the role of different categories of reciprocal peer coaching contexts in relation to teacher learning. The researchers found that teachers learn when they are intrinsically motivated to take part in professional development and when they are able to discuss their experiences within a safe and trustworthy reciprocal peer coaching environment.

Co-teaching is maintained for the second and third year field teaching experiences. This placement of paired novices in real-life classrooms enables those who have no teaching experience to work with someone else. It is envisioned that these two major practices will help to produce teachers who are reflective practitioners, critical thinkers, creative planners, problem solvers and researchers.

\subsection{Conceptual Framework}

Different orientations to teaching have been seen as significant factors that shape pre-service beginning teachers' expectations and beliefs about teaching. This study was guided by the conceptual framework of Calderhead and Shorrock (1997). This framework consists of academic, technical, practical, personal and critical orientations. The framework was considered appropriate as these orientations to teaching are representative of the skills and competencies that the University of Trinidad and Tobago envisages to be important to teacher education as they encompass the diverse ranges of the pre-service teachers' outcomes. Also, they present a non-judgmental perspective that views the different orientations as equally valuable to these pre-service beginning teachers' learning.

The academic orientation focused on the prospective teachers' subject expertise and saw the quality of the teachers' own subject matter knowledge as their professional strength.

The practical orientation emphasized the artistry and classroom technique of the prospective teacher. This view attaches the importance to classroom experience and apprenticeship models of learning to teach.

The technical orientation took into account the knowledge and behavioral skills that teachers require. It is derived from the behaviorist model of teaching and learning.

The personal orientation emphasized the importance of interpersonal relations in the classroom and views learning to teach as personal development within a safe environment that encourages exploration and discovery of personal strengths.

The critical orientation focused on the extent to which the teachers were able to blend theory into practice and become more critical and reflective.

For the purposes of the paper the practical and critical dimensions were combined since these orientations were focused on actual classroom experiences and the ability of the beginning teachers to make their links between theory and the reality of the classroom. 


\section{Review of the Relevant Literature}

There is a growing body of research that focuses on pre-service beginning teachers' beliefs, expectations and attitudinal changes that shape their perspectives on teaching and learning. Ozgun -Koca and Sen (2006), for example, examined pre-service teachers' beliefs and expectations about the teaching profession in the Turkey context. Their study focused on student-teachers' perceived changes in their perceptions at the end of their four-year programme. The study found that there were changes in the student teachers' beliefs about the learning environment to which they were exposed. It was felt that a more student-centered classroom was more conducive to effective learning. Other studies (Flores and Day, 2006) on teachers' beliefs and expectations recognized the influences of such beliefs on the ways beginning teachers think about teaching. The research indicated that student teachers' personal beliefs sometimes come into conflict with the realities of teaching that may lead to a sense of resignation that may shape their teacher identity. There is a need for professional guidance by mentoring teachers to expose them to the theoretical and practical aspects of teaching that can play a significant role in changing their perspectives about the profession. In this way there would be a culture of collaborative problem-solving that would strengthen school/university partnership and illustrate the synergy between theory and practice (Stuart \& Thurlow, 2000; de Leon - Carillo, 2007).

Becoming a professional teacher calls for extensive theoretical and practical studies that go far beyond initial teacher education courses. Practice worldwide has shown that novice teachers experience enormous difficulties when starting their working careers at school and many of them fail to survive the adaptation period (Krull, 2005). Some estimates suggest that over $40 \%$ of beginning teachers leave the profession within the first five years of teaching (Darling-Hammond \& Sclan, 1996). There is, thus, a great need for mentorship support from administration and for experienced teachers to introduce on-the-job field practice and induction programs so beginning teachers can integrate their formal pedagogical knowledge with practice of the actual school context (Hughes, 2003). Awaya, McEwan, Heyler, Linskey, and Wakuhama (2003) have noted the persons responsible for the guidance and support of beginning teachers are referred to using differing terminology depending on the nature of support provided and the support providers' role in organizing and supervising teaching practice. The name also depends on teacher education in a specific country. In the context of Trinidad and Tobago the term 'cooperating teacher' refers to those teachers who work with student-teachers in the school setting and 'practicum advisors' to the university professors and instructors who supervise student-teachers' school practice.

Tickle (2001), who has written on the value of mentoring, has indicated that such support is most effective when it is adjusted to the needs of beginning teachers during their initial practicum experiences. Veenman (1984) has also advocated the need for both instructional and psychological support for novice teachers. Instructional support assists novice teachers with the knowledge, skills and strategies necessary to be successful in the classroom, while psychological support provides confidence building, and encourages self-esteem.

The literature has highlighted further the importance of administrative and resource support for pre-service beginning teachers (Hawkey, 1997). The supportive works of Reiman and Parramore (1994) have also examined the discrepancy between beginning teachers" "what is" and "what should be". The "what is" relates to what the new teachers perceive as what is currently occurring, and "what should be" deals with what should be occurring to them in their situation. The studies concluded that adequate planning time, adequate resources and greater interaction between cooperating teachers and university supervisors are most important to beginning teachers' perceptions of success.

Indeed, such provision of on-site support and guidance during the beginning years helps novice teachers cultivate skills and habits that enable them to learn in and from their own practice. Such 'educative mentoring', according to Feiman-Nemser (2001), helps the new teachers blend theory with practice and fosters a principled understanding of teaching.

An essential component of the initial teaching practice and the process of learning to teach is the socialization process that trainees experience that should be grounded in classroom experience and the students' cultural and experiential background (Loughran \& Berry, 2005). The significant role of the cooperating teacher in assisting novice teachers to be confident and well-prepared for their future as teachers is well documented in the literature. Rajuan, Beijaard, and Verloop (2007), for example, cogently make the point that student teachers are most concerned about personal relationships with cooperating teachers, and with pupils as well about their own personal transition to teacher roles.

The influences of the school context and the personal background experience during pre-service education are also identified as important variables to be taken into account in the assessment of early teaching experiences. Yonk 
(1987) has identified two distinctive phases in beginning teachers' professional development: the threshold and the growing into the profession phases. The threshold phase encompasses the first year of teaching during which new teachers are confronted for the first time with a 'transition shock'. The growing into the profession phase is characterized by the acceptance of beginning teachers by their pupils and colleagues. During this phase the new teachers tend to focus their attention on skill development and pedagogical competencies.

Other studies (Alger, 2006) stress how beginning teachers make sense of the context and how such a context influences the decisions they make. The studies also emphasize that teacher education programs operate with the notion that reflection is a critically important characteristic and skill of an effective teacher and a tool for pre-service teachers to organize and reorganize their understanding, which leads to continuous professional development (Hatten and Smith, 1995). Richards and Lockhart (1994) describe reflection as a process in which teachers collect data about teaching, examine their attitudes, beliefs and assumptions, and teaching practices, and use the information obtained as a basis for critical analysis about their teaching.

In Trinidad and Tobago, given the infancy stage of the four-year Bachelor of Education, very little research has been done on pre-service teachers' practicum. Mention can be made, however, of a recent study that focused on an analysis of primary education in Trinidad and Tobago known as the Multi-Site Teacher Education Research (MUSTER) (George and Quamina-Aiyejina, 2003). The research examined many aspects of the teacher training program with the focus on trainees' views of themselves and the teaching profession and learning to teach. The research concluded, inter alia, that there was dissatisfaction by many trainees with the quality of mentoring as there was no structured program for the induction of beginning teachers. Novice teachers, in most instances, depended on an informal system of mentoring and assistance from cooperating teachers and school principals. It was recommended that adequate human and physical resources and a more structured program be put in place so that both mentors and novice teachers can work together to improve the quality of the teaching practice and teacher training on the whole.

A study by George, Worrell, and Rampersad (2002) on the preparation of teacher trainees for field experience, and the conduct of the actual practicum in Trinidad and Tobago found that the most significant messages emerged around three common themes: the role of theory, the nature of good teaching, and the methods for learning to teach. The findings of the research suggested that the messages helped trainees to shape the principal understandings that 'good' teaching is informed by practical experience shared by members of the teaching community. The findings suggested further that careful attention must be paid to major factors that seemed to shape these messages and understandings and the amount of reflective thinking in which trainees engage.

\section{The Research Questions}

The following research questions guided the study:

1) To what extent were there changes in the beliefs and expectations of the pre-service beginning teachers?

2) Was there adequate mentorship support for the pre-service teachers?

3) Were the pre-service teachers exposed to sufficient content to improve their expertise and subject matter competence?

4) Were there adequate classroom experiences for the pre-service teachers over the four year period to blend theory into practice?

\section{Methodology}

\subsection{Participants}

The participants in the study were 36 pre-service beginning teachers in a practicum class at the University of Trinidad and Tobago. The sampling was purposive (Patton, 1990) and the participants were easily accessible to the researchers over the four year period. There were 12 males and 24 females in the study. These novice teachers possessed a minimum of five CXC O' Level passes including Mathematics, English and a Science subject and were recent graduates from various secondary schools. These novices had no prior teaching experience and were never exposed to any teacher training program. Two ethical guidelines were taken into consideration: informed consent and confidentiality. Informed consent ensured that the participants entered the research of their free will and with an understanding of the study. Confidentiality involved the use of pseudonyms to conceal their identities (Mills, 2011). The study was conducted in two phases. The first phase was conducted in the first year (2007) at the students' initial entry to the university. The second phase (2011) was conducted with the same 36 students at the end of the final teaching practice. These students were exposed to the content and pedagogical knowledge and actual classroom 
experience over the four year period. The average age of the beginning teachers was 24 years and all agreed to participate from the beginning and at the end of the four year study.

\subsection{Data Collection and Analysis}

Data were collected through in-depth semi-structured individual interviews with the pre-service teachers at the beginning and at the end of the four-year period. For reasons of accuracy and harmony, tape recordings provided the major form of recording of information. Permission was sought and the respondents gave permission before the tape recordings were made. The following is a sample of the semi-structured interview schedule at the beginning and at the end of the four year period:

At the initial phase the students were asked the following questions prior to their first field experience:

$>\quad$ How does it feel to be a beginning teacher on teaching practice?

$>\quad$ What motivated you to want to teach?

$>\quad$ What are your beliefs about teaching?

$>\quad$ What are your expectations of the practicum?

$>\quad$ Are you adequately prepared to go on your practicum?

After the final practicum the students were again interviewed and responded to the following questions:

$>\quad$ To what extent have your initial beliefs about teaching changed?

$>\quad$ Have your expectations of the practicum been fulfilled?

$>\quad$ Do you feel adequately prepared with the content and pedagogical knowledge to teach after you graduate?

$>\quad$ What are your expectations of the practicum advisors and cooperating teachers in the mentoring process?

$>\quad$ How helpful were the cooperating teachers and the university advisors in assisting you in the planning and preparation of your lessons?

$>\quad$ Were there adequate resources to assist you in the delivery of your lessons?

$>\quad$ To what extent were you able to make links between theory and practice of teaching and learning in the classroom?

All the interviews were tape-recorded and transcribed verbatim. Transcriptions were returned to be checked for accuracy. There were two phases in the data analysis process : first, a vertical analysis process, according to which each of the pre-service teachers' interviews were separately analyzed ( Miles and Huberman, 1984). Second, a 'constant comparative analysis' (Glaser \& Strauss, 1967) was used to uncover key features, common patterns and emerging themes according to the overall principles of grounded theory (Glaser and Strauss,1967; Strauss and Corbin, 2007). A case record was also kept for each of the novice teachers over the four years as this enabled checking for recurring themes as well as contrasting patterns (Strauss and Corbin, 2007). During the coding process, all the interview data were thoroughly read through, and working labels were attached to the different emerging themes. The data were continuously revisited to ensure that they were reduced to a manageable size and any perceived changes over the four years with regard to teachers' beliefs and expectations and other practicum issues were not omitted (Stringer, 1996).

Five categories consistent with the conceptual framework of Calderhead and Shorrock (1997) were identified: beliefs and expectations, mentorship support, resource adequacy, sufficient content and pedagogical skills, and blending theory into practice. These themes were reflections of the beginning teachers' 'visions' of their practicum experiences over the four year period at the University of Trinidad and Tobago and were consistent with the research questions of the study.

\subsection{Findings and Interpretation}

Data were analyzed to answer each research question. The findings were revealed through the use of descriptive and interpretive statements based on the interviews with the pre-service beginning teachers at the beginning and at the end of the four-year practicum.

\section{1) Research question 1: Changes in beliefs and expectations}

The majority of the beginning teachers $(80 \%)$ were of the view that their beliefs and expectations about the practicum and teaching as a whole have changed over the four year period. Among the comments regarding beliefs and expectations were the following: 
My initial beliefs of teaching have changed drastically after completing and being exposed to the practicum experiences. This has broadened my knowledge about various strategies to which all knowledge is applied (Pre-Service Teacher, 3).

My beliefs about teaching have changed a bit. Students are no longer like long time. You have to use plenty resources and preparation in teaching $(\mathrm{PT}, 5)$.

My beliefs about teaching have had a drastic change. It is not just going to the classroom and completing the syllabus of work. I believe that all children are capable of learning and it just takes us as educators to figure out the best possible environment in which children can learn. Some learn better one on one, some in group and so on (PT, 8).

I used to believe that the teacher knows more than the student. Now I know that the teacher does not know everything. I see teaching as a learning experience and the teacher as a facilitator and a strategist. I also see the importance of making the classroom safe and conducive to learning and that learning does not only take place in the classroom (PT, 9).

My beliefs have changed in the sense that now I am more exposed to all the things needed to become an effective teacher. It has taken my thoughts to the extent to where it was not at the beginning. Now I feel as though I am more prepared to become a teacher $(\mathrm{PT}, 10)$

A few student teachers (20\%), however, felt that there were some changes, while others felt that there were no changes in their beliefs and expectations over the four year period. The following are some of their responses:

My initial belief about teaching has not changed much. It has been strengthened and supported by the things I have learned. The practicum program has opened my eyes a little bit to help me in my future teaching (PT, 12).

My beliefs about teaching have not changed. I still believe that in order for one to be a good teacher one must have love for children. I love for children even before I came to the university to learn to teach (PT, 14).

I would say that my expectations of the practicum have been fulfilled to the extent that I have gained the experience to work with a large number of students and I have learnt about the culture of different schools. I have been able to reflect on my teaching abilities and make changes as I learnt a lot both at the university and the classroom (PT, 20).

My expectations of the practicum has been partially fulfilled. I did not get enough time to plan my lessons and there was not enough help in checking lesson plans and units as well as proper advice from the practicum advisors (PT, 18).

My expectation of the practicum has been fulfilled in some ways. I am quite disappointed since the practicum is disorganized, especially with the selection of schools for teaching practice. Nonetheless, I am quite grateful and appreciative of the teaching experiences I have encountered. I feel that I am now better prepared to teach in a real class situation (PT, 13).

My expectation of the practicum has been fulfilled to the extent that I was exposed to challenging experiences and I learnt a lot of teaching techniques that I did not know before I entered the university (PT, 14).

The perceptions of the majority of novice teachers about their beliefs listed above suggest that these student- teachers held prior beliefs on entry to the university. These prior beliefs about teaching were love for children and the teaching profession as a whole. However, over the four year period there were changes with regard to how they viewed teaching and learning. Some of these changes in their beliefs and expectations were enhanced teaching techniques and greater self- confidence. These findings are supported by the works of Feiman-Nemser, (2001), who argues that pre-service beginning teachers need to analyze their beliefs and form new visions, develop subject matter knowledge and learn the context, students and the wider community. Flores, (2001) research has noted the powerful influences of students' prior experiences and beliefs on workplace conditions. Other research has indicated that student teachers bring their prior knowledge to new learning situations and build upon it to improve their teaching and learning competencies (Leinhardt, 1992).

\section{2) Research question 2: Mentorship support}

All the students interviewed (100\%) were of the view that mentorship support from the university practicum advisors and the teachers and principals from the practicing schools were vital for professional development as beginning teachers. While the majority (70\%) felt that they did get the emotional and professional support (Little, 2002) from the university and their respective schools, others indicated (20\%) that there were many shortcomings with regard to the assistance they needed. 
The following are some of the positive comments from the beginning teachers with regard to their feeling of confidence, building of positive self- esteem and adequate feedback to improve their professional practice:

My practicum advisor guided me and gave me excellent feedback on the lessons taught. She also gave tips on how to improve specific lessons. I still feel that she needs some sort of professional training (PT,12).

My practicum advisor gave me tremendous support. He ensured that I had adequate resources and helped me in the management of my class and the effective delivery of the lessons (PT, 20).

My practicum advisor helped me to build my self- confidence when he saw that I was nervous and not sure of myself. He also gave me sound advice on how to deal with children of mixed ability and those from a different cultural background (PT, 25).

The cooperating teachers were very helpful and were always willing to give advice to help my teaching experience (PT, 9).

I learnt a great deal from my cooperating teacher who was very helpful, kind and patient. I was able to get timely feedback which was very beneficial to me (PT, 32).

Indeed, research has indicated that such on-site support and guidance is necessary so that new teachers will know how to blend knowledge of particular students and content in decisions about what to do in specific situations (Little, 1990). Feiman -Nemser (2001) has also cogently pointed out that such 'educative mentoring' promotes beginning teacher development by cultivating a disposition of inquiry, focusing attention on student thinking and understanding and fostering disciplined talk about problems of practice.

The important role of the university practicum advisor as a facilitator, personal confidante, and trusted guide is viewed as a key element in the ecological transitions that take place during the teaching practice and also as a vital source of emotional support and guide of the learning to teach process (Caires and Almeida, 2005; Hawkey, 1997; Beck and Kosnik, 2000).

Mentorship support from the school, such as collaboration and mutual help, encouraging gestures, feedback, respect and honesty, gives novice teachers feelings of preparedness which are significantly related to these new teachers' sense of efficacy and their confidence to achieve teaching goals (Darling-Hammond, Chung and Frelow, 2002; Holloway, 2001; Postholm,2008).

Feedback was also seen as an important ingredient in helping beginning teachers make sense of their context and gives them an opportunity to identify gaps between current and desired performance and to take action to close the gap (White, 2007).

Some of the novice teachers (20\%), while recognizing the need for strong mentoring, felt, however, that there was not sufficient support and guidance given by the university practicum advisors and the cooperating teachers at the practicing schools. The following are examples of some of the views expressed by these beginning teachers:

My practicum advisor neither came to the school nor sent someone to assist me in my planning and supervision of my lessons (PT, 28).

I was not able to reach the practicum advisor to discuss any matter out of the classroom which made it difficult for me. She also contradicted what she said in class when we were out in the field (PT, 1).

Some cooperating teachers were very helpful and understanding, while some ignored us and gave us "the cold shoulder' as though we were intruding in their class (PT, 11).

The cooperating teachers were absent on many occasions and I had to teach the class for the whole day (PT, 31).

Many of the cooperating teachers were accommodating and gave good guidance. However, some of them did not know how to talk professionally and need some training in advising new teachers. They want us to teach what they tell us and not what we were prepared to teach (PT, 33).

Although my cooperating teacher was helpful, I felt that she was lacking in advising me on my pedagogical areas of weakness (PT, 4).

My practicum advisor, on many occasions, did not give me adequate feedback to improve myself (PT, 6).

The above comments from a sample of the novice teachers' views on the need to have more guidance from the school and the university are supported in the literature. Hawkey (1998), for example, analyzed mentor training and mentoring relations and found that beginning teachers need to feel sufficiently empowered to influence their mentoring experience so that their individual needs and experience are satisfied. Such empowerment is built on a 
high degree of trust and confidence between these novice teachers and their mentors. Other research studies on the importance of the collaboration between the novice teachers and the mentors focus on the need to cultivate 'expert' teachers and advisors who can be exemplars and models for novice teachers to help them develop positive self-esteem, a feeling of confidence, enthusiasm and care for all children so that all will have equal chances to achieve and flourish (Leinhardt and Greeno, 1986). These exemplars, both from the practicing schools and the university and other tertiary institutions, will be involved in 'educative mentoring' (Feiman-Nemser, 2001), will be able to give professional and emotional support (Little, 1990), and reflective feedback, both oral and written (McMahon, 1997; Hattie and Timperly, 2007; Uhlenbeck, Verloop, and Beijaard, 2002), so that novice teachers will have a clear focus and direction for future professional practice. In this way they will develop broad conceptions of teaching and make sense of the students and classroom and how their understandings influence the decisions they make.

\section{3) Research question 3: Sufficient content and pedagogy}

In this category there were mixed messages by the beginning teachers who were equally divided with regard to the adequacy of pedagogical content knowledge they were exposed to over the four year period. While about $50 \%$ were of the view that there were sufficient content and pedagogy, about $50 \%$ felt that there were insufficient content and pedagogy over the four year period. The following are a sample of their reflections of some of the beginning teachers in this area:

I feel fifty percent prepared because specific subject lessons were not checked by the specialized lecturers. I feel 'at sea' in some areas that I am not so strong in as mathematics and science (PT, 33).

I feel somewhat prepared in certain subjects as I was exposed to the different theories of teaching, and the different approaches and methodologies in the practicum classes over the four years. Some lecturers knew the content but were weak in putting it across to students (PT, 18).

I feel prepared to a certain extent. The course to which I was exposed did not give me enough skills and strategies to deliver lessons effectively in the classroom (PT, 35).

I have a lot more knowledge now to be able to relate to students. The different practicum courses over the four years assisted me to be more aware of the individual differences in the school and how to deal with exceptionalities (PT, 22).

Although I have not mastered a lot of skills in teaching, I feel that different content and pedagogy I got made me more aware of the complexities of teaching and how to deal with them in the actual class context (PT, 16).

The content and pedagogy were too much to absorb and sometimes there was a lot of confusion since there was, at times, conflicting approaches by different lecturers in the planning of lessons. Lecturers need to be on the same 'page' in advising students in unit and lesson planning to avoid confusion among students (PT, 26).

Indeed, these comments by the novice teachers on the lack of coherence of the content and pedagogy of the practicum are not uncommon in pre-service teacher preparation programs. Some researchers have noted that conventional pre-service teacher education, in many instances, is characterized by fragmentation, weak pedagogy, lack of articulation among courses and field experience and an absence of a set of organizing themes, shared standards and clear goals ( Zeichner, 1992; Feiman-Nemser, 2001). Another researcher has advocated the need to have more reflective and action research courses so that the novice teachers can become critical thinkers and independent learners (Adler, 1991). Such more reflective and practical-oriented courses will allow students to be better placed to critically examine their practice, values and assumptions, as well as give them a better understanding of themselves, beliefs, values, assumptions and patterns of emotions that structure their behaviour in the classroom (Richert, 1990).

\section{4) Research question 4: Adequate classroom experience to blend theory into practice}

Although over the four year period the beginning teachers were exposed to eight weeks of practicum, they felt that too much time was spent on planning, in-house seminars and observation rather than actual real life experience. The vast majority of the students interviewed (93\%) were of the view that they were not exposed to adequate classroom experience to develop themselves professionally and blend theory into practice. The following are samples of the views of these students:

There was not enough practice in the second and third years. The field experiences are too important to have such limited time in the classroom (PT, 19). 
There is too much observation and too little teaching. I believe that more teaching sessions are needed so that we will be able to get familiar with the classroom (PT, 35).

I was a bit disappointed in the actual teaching. The final year was good with six teaching weeks, but in the second and third years we were not exposed enough to the actual classroom where all the action is. I learn more from experience rather than in-house sessions (PT, 21).

There is a saying that 'practice makes perfect'. This should apply to the practicum at the university. There is too much planning and in-house seminars and little exposure to the context where we get to know children better and learn from our mistakes (PT, 32).

We have to be more serious at the university when it comes to the classroom experience. A couple days are not enough to fully get a grasp of a classroom and the skills needed to carry out what is to be done. More actual real-life experience and sessions are needed (PT, 23).

It is possible to some extent. However, some theories seem irrelevant when you have to teach a classroom of diverse learners (PT, 17).

I was able to make some links between theory and practice in the classroom by looking at students and their behavior. I was able to identify, to some extent, some of the students' problems based on what I learnt in class (PT, 22).

The theories learnt in the previous years aided me to the extent that I was able to plan and execute my lessons effectively (PT, 25).

There was too much theory that got me confused. I did not know how to apply all these theories in the actual classroom (PT, 27).

There were very little links between theory and practice in the seminar sessions. Since I have no experience in teaching it was extremely difficult to put theory into practice in the class (PT, 31).

To some extent it was possible. The classroom is not ideal and some theories were difficult to understand especially when you have to teach a class with so much diverse children (PT, 6).

The above comments from these beginning teachers indicate that there is strong dissatisfaction among these novice teachers with regard to their actual classroom experiences to nurture and develop them professionally so that they will be able to face up to the challenges when they are in the actual school and class setting. Some researchers have called for a more holistic practice-based approach (Hollins, 2011) so that there would be conceptual coherence that integrates subject matter competence with field experience with the focus on teachers as learners (Feiman-Nemser, 2001). Such holistic approach and balance between theory and practice would help beginning teachers translate their pedagogical content knowledge with the classroom context that should meet the standards and trustworthiness for accomplishing the desired outcomes for particular learners.

Shulman (1987) has underscored the need to close this gap between theory and practice in this age of transformation of teacher education. Other related studies have recognized that no matter what kind of preparation a new teacher receives, no college course or courses can teach how to blend knowledge of particular students and context in decisions about what to do in specific situations (Carr, 1980; Tickle, 2001). Such practical experiences will help students develop 'connective insights' so they can see how their biographies influence their pedagogical judgment to deal competently with classroom situations that are unpredictable (Ball and Forzani, 2009).

\section{Discussion and Recommendations}

The results of the study, while limited to the perspectives of 36 pre-service beginning teachers, suggest, inter alia, that greater emphasis be placed on developing the professional competence of cooperating teachers, school principals and university advisors so that they can develop a wide range of competencies and skills to guide and nurture new teachers who are now entering the teaching profession. Herbert and Worthy (2001) have explored the impact on the personal and professional lives of beginning teachers in the first year of teaching. Their findings have indicated that in these early years novice teachers encounter numerous new challenges and responsibilities as they strive to find a professional place within the school culture.

While the University of Trinidad and Tobago has embarked on a more transformative approach towards teacher preparation, there still persists no structured program to train mentors both at the school and university levels to support the pre-service teachers. Also, there is little collaboration between the practicing schools and the university to assist beginning teachers to value practice and build the bridge between theory and practice. 
One of the pressing challenges that the University of Trinidad and Tobago and other tertiary teacher education institutions is facing is how to improve the quality of the mentoring programme. While in some schools both the mentor teachers and the principals possess the required mentorship competence and skills, in other schools the cooperating teachers and school principals do not have such competencies. At present there is an ongoing intensive mentorship programme that focuses on the professional preparation of these teachers and principals to create a professional knowledge base with opportunities to enhance their own understanding of the reflective process and develop a culture of collaboration beyond initial teacher preparation (Senturk, 2007).

Change is slow as there is still the traditional model of the practicum where student teachers are the consumers of knowledge and the practicum advisors are the producers of knowledge (Leinhardt and Greeno, 1986). In Trinidad and Tobago and the wider Caribbean there is still the university-led approach where the university personnel plays a major role in determining where students should learn and how they are assessed. More has to be done to close the gap between theory and practice. Such changes would involve a recognition that learning to teach is a process that continues throughout a teacher's career. Teacher education must be committed to helping prospective teachers internalize the dispositions and skills to study their teaching, become better teachers over time and take responsibility for their own professional development. In so doing these new teachers will assume their rightful place as leaders of educational reform.

At the University of Trinidad and Tobago there is a gradual movement to a more developmental model (George et al, 2002), with greater linkages between the university, the practicing schools and the schools to which students are assigned upon graduation. In this long-term partnership experienced teachers will share their wisdom, competencies and skills as well as their moral commitment towards enabling students to learn.

Zeichner (2006) succinctly makes the point that there is a need for practice-based teacher education programmes to help novice teachers develop an ability to reflect on teacher effectiveness and view teaching as a student and as a teacher.

It is heartening to note that attempts are being made at the University to develop a professional learning community with schools while students are at the university and when they graduate and go to respective schools. Little (2002) has noted that with such a professional community there is increased sense of work efficacy, increased classroom management and greater collective responsibility for student learning. Similar studies by Morrisey (2000) have found that a professional learning community enhances teacher effectiveness as professionals and beliefs among teachers of their power to make a difference in students' learning. Stoll, Bolam, McMahon, Wallace, and Thomas (2006) have further underscored the need to develop in pre-service teachers the social and intellectual capacities to enable them to participate in ethical and socially responsible ways in professional learning communities.

More support is needed from all the stakeholders such as the Ministry of Education, schools, Denominational School Boards, Teacher Associations and other key stakeholders. Such a 'blended' or partnership model (Bryk, Harding, Greenberg, 2012) will strengthen the link between novice teachers and the schools they are going into to teach and, thus, help to create seamless clinical experiences and a professional culture (Sanzo, Sherman and Clayton, 2011) that would allow for more competent future teachers who are guided by effective principals. Indeed, framing such professional experience around the notions of learning communities and 'communities of practice' (Wenger,1999; Wenger, McDermott and Snyder, 2002) in this twin island state of Trinidad and Tobago will support our pre-service beginning teachers to work with peers and mentor teachers in more collegial and reciprocal ways. They will be actively involved in learning relationships with a range of colleagues characterized by trust, with a strong appreciation of the critical nature of professional conversations for ongoing professional learning. In such 'communities of practice' the novice teachers, practicum advisors and school personnel will be engaged in a process of collective learning in a shared domain of human endeavor, share a passion for something they do or learn and be involved in a set of relationships over time.

\section{References}

Adler, S. (1991). The reflective practitioner and the curriculum of teacher education. Journal of Education for Teaching, 17(2), 139-150. http://dx.doi.org/10.1080/0260747910170203

Alger, C. (2006). What went well, what didn't go so well: growth of reflection in pre-service teachers. Reflective Practice, 7 (3), 287-301. http://dx.doi.org/10.1080/14623940600837327

Awaya, A.H., McEwan, D., Heyler,S., Linsky, D., \& Wakuhama, P. (2003). Mentoring as a journey. Teaching and Teacher Education, 19(1), 45-56. http://dx.doi.org/10.1016/S0742-051X(02)00093-8 
Ball, D. L., \& Forzani, F M. (2009). The work of teaching and the challenge for teacher education. Journal of Teacher Education, 60(5), 497-511. http://dx.doi.org/10.1177/0022487109348479

Beck, C., \& Kosnik , C. (2000). Associate teachers in pre-service education: Clarifying and enhancing their role. Journal of Education for Teaching, 26(3), 207-224. http://dx.doi.org/10.1080/713676888

Bryk, A.S., Harding, H., \& Greenberg, S. (2012). Contextual influence on inquiries into effective teaching and their implications for improving student learning. Harvard Educational Review, 82(1), 83-106.

Caires, S. and Almeida, L. S. (2005). Teaching practice in critical teacher education: its impact on student teachers' professional skills and development. Journal of Education for Teaching, 31 (2), 111-120. http://dx.doi.org/10.1080/02607470500127236

Calderhead, J., \& Shorrock, S. (1997). Understanding teacher education. London: The Falmer Press.

Carr, W. (1980). The gap between theory and practice. Journal of Further and Higher Education, 4(1), 60-69. http://dx.doi.org/10.1080/0309877800040107

Darling-Hammond, L., Chung, R., and Frelow, F. (2002).Variation in teacher preparation: how well do different pathways prepare teachers to teach? Journal of Teacher Education, 53 (4), 286-302. http://dx.doi.org/10.1177/0022487102053004002

Darling-Hammond, L., \& Sclan, E.M. (1996). Who teaches and why: Dilemmas of building a profession for twenty first schools. In Handbook of research in teacher education. $2^{\text {nd }}$. ed. New York: Macmillan.

De Leon-Carillo, C. M. (2007).Prospective teachers' pre and post-practicum beliefs on teaching. Journal of Educational Policy, 4 (1), 25-40.

Feiman-Nemser, S. (2001).Helping novices learn to teach. Journal of Teacher Education, 52 (1), 17-30. http://dx.doi.org/10.1177/0022487101052001003

Flores, M. A. (2001). Persons and context in becoming a new teacher. Journal of Education for Teaching,27(2), 138-148. http://dx.doi.org/10.1080/02607470120067882

Flores, M. A., and Day, C. (2006). Contexts which shape and reshape new teachers' identities: a multi-perspective study. Teaching and Teacher Education, 22, 219-232. http://dx.doi.org/10.1016/j.tate.2005.09.002

George, J., Worrell, P., and Rampersad, J. (2002). Messages about good teaching: Primary teacher trainee's experience of the practicum in Trinidad and Tobago. International Journal of Educational Development, 22, 291-304. http://dx.doi.org/10.1016/S0738-0593(01)00067-0

George, J., \& Quamina - Aiyejina, L. (2003). An analysis of primary teacher education in Trinidad and Tobago: Department of International Development Publication, Seven Oaks, United Kingdom. http://dx.doi.org/10.1080/0305792032000070048

Glaser, B., \& Strauss, A. (1967). The discovery of grounded theory. Aldine, Chicago.

Hattie, J., \& Timperley, H. (2007). The power of feedback: Review of the literature. Review of Educational Research, 77(1), 81-112. http://dx.doi.org/10.3102/003465430298487

Hatten, N., \& Smith, D. (1995). Reflection in teacher education: Towards definition and implementation. Teaching and Teaching Education, 11(1), 33-49. http://dx.doi.org/10.1016/0742-051X(94)00012-U

Holloway, J. (2001). Benefits of mentoring. Educational Leadership, 58(8), 85-86.

Hawkey, K. (1998). Mentor pedagogy and student teacher professional development: A study of two mentoring relationships. Teaching and Teacher Education, 14 (6), 657-670. http://dx.doi.org/10.1016/S0742-051X(98)00015-8

Hawkey, K. (1997). Roles, responsibilities and relationships in mentoring: A literature review and agenda for research. Journal of Teacher Education, (48), 325-335. http://dx.doi.org/10.1177/0022487197048005002

Herbert, E., \& Worthy, T. (2001). Does the first year of teaching have to be a bad one ? A case study of success. Teaching and Teacher Education, 17(8), 897-911. http://dx.doi.org/10.1016/S0742-051X(01)00039-7

Hollins, E. R. (2011). Teacher preparation for quality teaching. Journal of Teacher Education, 62(4), 395-401. http://dx.doi.org/10.1177/0022487111409415

Hughes, M. (2003). Mentoring. In Encyclopedia of Education (2 ${ }^{\text {nd }}$. Ed.), (5), 1618-1620. 
Kagan, D.M. (1992). Implications of research on teachers' beliefs. Educational Psychologist,27, 65-90.Krull, E. (2005). Mentoring as a means for supporting student and beginning teachers' practice-based learning. Frames, 9(2), 143-158.

Leinhardt, G. \& Greeno, J. G. (1986). The cognitive skill of teaching. Journal of Educational Psychology, 78(2), 75-95. http://dx.doi.org/10.1037/0022-0663.78.2.75

Leinhardt, G. (1992). What research on learning tells us about teaching. Educational Leadership, 49 (7), 20-25.

Little, J.W. (1990). The mentor phenomenon and the social organization of teaching. Review in Research in Education, 16, 297-351.

Little, J. W. (2002). Locating learning in teachers' communities of practice : opening up problems of analysis in records of everyday work. Teaching and Teacher Education,18(8), 917-946. http://dx.doi.org/10.1016/S0742-051X(02)00052-5

Loughran, J., \& Berry, A. (2005). Modeling by teacher educators. Teaching and Teacher Education, 21, 193-203. http://dx.doi.org/10.1016/j.tate.2004.12.005

Mc Mahon, S. I. (1997).Using documented written and oral dialogue to understand and challenge pre-service teachers' reflection. Teaching and Teacher Education, 13 (2), 199-213. http://dx.doi.org/10.1016/S0742-051X(96)00016-9

Miles, M.B., \& Huberman, A.M. (1984). Qualitative data analysis : a source book of new methods. London : Sage Publications.

Mills, G. E. (2011). Action research : A guide for the teacher researcher (fourth edition). Pearson, New York.

Morrissey, M. S. (2000). Professional learning communities : an ongoing exploration. Austin Texas: Southwest Educational Laboratory.

Nokes, J., Boulough Jr, R., Egan, W., Birrell, J. \& Hansen, M. (2008). The paired placement of student teachers: An alternative to traditional placements in secondary schools. Teaching and Teaching Education, 22, 2168-2177. http://dx.doi.org/10.1016/j.tate.2008.05.001

Ozgun-Koca, S. A., and Sen, A. I. (2006).The beliefs and perceptions of pre-service teachers enrolled in subject-area dominant teacher education program about 'effective education'. Teaching and Teacher Education, 22, 946-960. http://dx.doi.org/10.1016/j.tate.2006.04.036

Patton, M.Q. (1990). Qualitative evaluation and research method, $2^{\text {nd }}$ ed., Sage Publications, Newbury. Park,CA.

Postholm, M. (2008). Teachers developing practice: Reflection as a key activity. Teaching and Teacher Education, 24, 2168-2177. http://dx.doi.org/10.1016/j.tate.2008.02.024

Rajuan, M., Beijaard; \& Verloop, N. (2007). The role of the cooperating teacher: Bridging the gap between the expectations of cooperating teachers and student teachers. Mentoring and Tutoring, 15 (3), 223-242. http://dx.doi.org/10.1080/13611260701201703

Richert, A. (1990). Teaching teachers to reflect: A consideration of programme structure. Journal of Curriculum Studies, 22, 509-527. http://dx.doi.org/10.1080/0022027900220601

Richards, J.C., \& Lockhart, C. (1994). Reflective teaching in second language Classrooms.. Cambridge, Cambridge University Press. http://dx.doi.org/10.1017/CBO9780511667169

Reiman, A.J., \& Parramore, B. (1994). First-year teachers' assignments, expectations and development. In M. O’Hair \& S. Odell (Ed.), Partnerships in Education (pp.120-134). New York: Harcourt, Brace and Jovanovich.

Sanzo, K. L., Sherman, W. H., \& Clayton, J. ( 2011). Leadership practices of successful middle school principals. Journal of Educational Administration, 49(1), 31-45. http://dx.doi.org/10.1108/09578231111102045

Shulman, L. (1987). Knowledge and teaching: Foundations of the new reform. Harvard Educational Review, 57 , $1-22$.

Senturk, H. (2007). Student teachers' perceptions of classroom management models used by expert teachers. The Journal of Special Education, 4 (3), 598-603.

Stoll, L., Bolam, R., McMahon, A., Wallace, M. \& Thomas, S. (2006). Professional learning communities: a review of the literature. Journal of Educational Change, 221-258. http://dx.doi.org/10.1007/s10833-006-0001-8

Stringer ,E. T. (1996). Action research: A handbook for practitioners. Thousand Oaks, CA, Sage. 
Strauss, A. \& Corbin, J. (2007). Basics of qualitative research : Techniques and procedures for developing grounded theory, $2^{\text {nd }}$ ed, Sage, Thousand Oaks, CA.

Stuart, C., and Thurlow, D. (2000). Making it their own: Pre-service teachers' experiences, beliefs and classroom practices. Journal of Teacher Education, 51(2), 113-121. http://dx.doi.org/10.1177/002248710005100205

Tickle, L. (2001). The organic intellectual educator. Cambridge Journal of Education. 31(2), 159-176. http://dx.doi.org/10.1080/0305764012006128

Tompkins, G. E. (2006). Characteristics of a community of learners. Allyn and Bacon.

Trinidad and Tobago, National Task Force on Education. (1994). Education Policy Paper (1993-2003) (White Paper). Ministry of Education, Port-of Spain.

Uhlenbeck, A. M., Verloop, N., and Beijaard, D. (2002). Requirements for an assessment procedure for beginning teachers: Implications from recent theories on teaching and assessment. Teachers College Record, 104 (2), 242-272. http://dx.doi.org/10.1111/1467-9620.00162

Veenman, S. (1984). Perceived problems of beginning teachers. Review of Educational Research, 54(2), 143-178.

Wenger, E. (1999). Communities of practice, learning meaning and identity. New York : Cambridge University Press.

Wenger, E., McDermott, R.,\& Snyder, W. (2002). Cultivating communities of practice ; A Guide to managing knowledge .Boston, Mass.: Harvard Business School Press.

Wilson, G., \& I' Anson, J. (2006). Reframing the practicum: constructing performative space in initial teacher education. Teaching and Teacher Education, 22, 353-361. http://dx.doi.org/10.1016/j.tate.2005.11.006

White, S. (2007). Investigating effective feedback practice for pre-service teacher education students on practicum. Teaching Education, 18(4), 299-311. http://dx.doi.org/10.1080/10476210701687591

Yonk, J.H.C. (1987). Beginning teachers 'professional development and its implication for teacher education and training. The Irish Journal of Education, 23(1), 5-21.

Zeichner, K. (1992). Rethinking the practicum in the professional school partnership. Journal of Teacher Education, 43(4), 296-307. http://dx.doi.org/10.1177/0022487192043004009

Zeichner, K. (2006). Reflections of a university-based teacher educator on the future of college-and university-based teacher education. Journal of Teacher Education, 57(3), 326-340. http://dx.doi.org/10.1177/0022487105285893

Zwart, R.C., Wubbles, T., Bergen, T., \& Bolhuis, S. (2009). Which characteristics of a reciprocal peer coaching context affect teacher learning as perceived by teachers and their students. Journal of Teacher Education. 60(3), 243-257. http://dx.doi.org/10.1177/0022487109336968 